\title{
JUSTICE AND ELECTORAL DISPUTES IN MOZAMBIQUE
}

\author{
By
Gilles Cistac
}

Dr Gilles Cistac PhD magna cum laude, 1998, Toulouse University, is Professor of Law and Coordinator of the Master Course Program, Coordinator of the Research Centre on Public Administration and Local

Development Faculty of Law University Eduardo Mondlane Av Kenneth Kaunda 960 CP 257 Maputo Mozambique Tel: (258) 21488882; Fax: (258) 21415364; Cell: (258) 823030520

e-mail:gilles.cistac@uem.mz

\begin{abstract}
A doctrinal practical study of the Mozambican electoral dispute procedure reveals some specific characteristics. Firstly, there is no precise correspondence between the procedure and electoral jurisdiction; what characterises the Mozambican electoral dispute procedure is the diversity of the procedures within the electoral process. Secondly, the dispute procedures are integrated because they cover pre-election and post-election disputes simultaneously. Thirdly, the structure is that of administrative dispute procedure. Finally, the authority of the electoral judge is an aggregate of both the control of the regularity of electoral procedures and the control of the veracity of the elections. Delicate questions, such as the scope of the powers of the Constitutional Council, the confirmation or not of the 'principle of sua sponte examination or evidentiary inquiry' and the position of the Constitutional Council in relation to the correction of the election results are still unresolved.
\end{abstract}

\section{INTRODUCTION}

If, in Mozambique, there are military, customs, administrative, maritime and labour law jurisdictions, why should there not be a system of electoral justice?*

* Translator's Note: The word 'justiça' as used in this paper does not have precisely the same meaning and usage as the English word 'justice'. The term 'justiça' in Portuguese connotes a system of justice, law, jurisdiction (power of a court or other body over particular subject matter). The word 'justice' in English (reflecting the common law system) currently connotes the fair administration of law and is also the title applied to certain types of judges, although historically, under feudal law, it meant jurisdiction, cognisance, and judicial power. To maintain the 'rhythm' of the author's usage of the term 'justiça eleitoral', I have therefore used the term as directly translated when there is a general reference, that is, 'electoral justice', but not where the precise translated English meaning requires the usage of the terms: 'law', 'jurisdiction', 'system of justice', and so on. 
The term 'electoral justice' does not formally appear in the Mozambican Constitution. ${ }^{1}$ Art 167 of the Fundamental Law does not contemplate 'electoral tribunals' within the classification of the different state jurisdictions. But must this necessarily mean that there is no 'electoral justice'?

Could it be that all the elements and component parts of such an area of jurisdiction are, in fact, present in the Fundamental Law of the Republic and / or in other legislation that is relevant to the issue?

The specifics of the conflict resolution structure for electoral disputes, broadly construed, in Mozambique, lead to a study that is not limited to the question of the existence or not of an 'electoral system of justice'. Electoral disputes are part of electoral jurisdiction, but do not wholly fall within the system of electoral justice, whose make-up integrates a complex series of factors that make it unique and distinctive.

As a general rule electoral dispute procedures regulate the organisation and procedures within the system of electoral jurisdiction. In other words, they consist in 'the set of legal rules that regulate the production and development of the acts and formalities required for the achievement of the aforesaid aims' (Freire Barros 1998, p 18) and are the process for the resolution of differences with regard to the interpretation or application of the rules that govern the electoral process'. ${ }^{2}$

The doctrinal practical study of Mozambican electoral dispute procedures reveals some specific characteristics. Firstly, there is no precise correspondence between these procedure and electoral jurisdiction; what characterises them is the diversity of the procedures within the electoral process. Secondly, the procedures are integrated because they cover pre-election and post-election disputes simultaneously. Thirdly, their structure is that of an administrative dispute procedure. Finally, the authority of the electoral judge is an aggregate of control both of the regularity of electoral procedures and of the veracity of the elections.

\section{The Multiple Forums of the Electoral Dispute PROCEDURES}

In the electoral dispute procedures 'the law attributes the competence to decide complaints to diverse instances' (Constitutional Council Decision no*17/CC/04 of 3 June 2004). These 'instances' together form, within the Mozambican legal order, non-jurisdictional electoral dispute procedures and jurisdictional electoral dispute procedures.

1 This study was undertaken taking into account the law in effect until the entry into force of the new Constitution of 22 December 2004.

2 Electoral Dispute (Contencioso electoral), in the Glossary of legal terms used in the Electoral Law (Law 7/ 2004 of 17 June).

* Hereafter referred to as Decision no ... 


\section{Non-Jurisdictional Electoral Dispute Procedure}

The non-jurisdictional electoral dispute procedure is made up of complaints and protests directed at and decided by the electoral administration as the competent administrative authority with the duty to guarantee the transparency and objectivity of the electoral process and the principle of equality.

In this regard, the role of the Constitutional Council is to give direction to the organisation of the non-jurisdictional electoral dispute procedure between the 'first instance' and the 'second instance'.

\section{THE ‘FIRST INSTANCE’}

\section{Voting precinct board}

According to Decision no17/CC / 04 of 3 June 2004, the voting precinct board, that is, 'the group of persons charged with the conduct of the tasks in each voting precinct ${ }^{\prime 3}$ has the competence to decide on complaints and protests about the general electoral activities conducted by the board (Art 78.1 of Law 7/ 2004 of 17 June and Arts 75.1 and 75.4 of Law 19/2002 of 10 October) and about the preliminary voting results (Art 89.1 of Law 7/ 2004 of 17 June; Art 87.3 of Law 19/ 2002 of 10 October). ${ }^{4}$

\section{The election boards at district and city level}

The district and city election boards, the 'National Electoral Commission support bodies', decide on 'the complaints, protests and counter-protests that are submitted' for the first time (Art 23 of Law 20/ 2002 of 10 October and Art 96.1 of Law 19/ 2002 of 10 October).

\section{Provincial election boards}

The provincial election boards, which are responsible for the determination of the voting results from the electoral precincts within a province (Art 97 of Law 7/ 2004 of 17 June) have the power to decide, in the first instance, on complaints, protests and counter-protests (Art 102 of Law 7/ 2004 of 17 June).

\section{The National Electoral Commission}

The National Electoral Commission, created by Law 20/2002 of 10 October, is the most important permanent electoral administration body and has the initial

3 See Glossary of legal terms in Law 7/ 2004 of 17 June. See also Art 56 of Law 7/ 2004 of 17 June.

4 Effectively, in the latter case it is assumed that the voting precinct board has taken a decision about the validity of the ballot. 
administrative jurisdiction over electoral dispute procedures. This jurisdiction is based on the provisions of Art 7.2 of Law 7/2004 of 17 June, which stipulates: 'Without prejudice to the respective competence of the Constitutional Council, the National Electoral Commission has the competence to verify the regularity and validity of the acts of the electoral process.'

In addition to controlling and supervising the electoral process (Art 7.1 of Law $7 / 2004$ of 17 June) the commission verifies its regularity and legality (Art 7.2 of Law $7 / 2004$ of 17 June).

- Within the scope of municipal elections, the commission undertakes the verification of the candidates (Art 17 of Law 19/2002 of 10 October) and any rejection of candidates as provided in Art 19 of Law 19/2002 of 10 October. $^{5}$ As a general rule, any irregularities that occur during voting may be reviewed by the commission (Art 137.1 of Law 19/2002 of 10 October ) in the 'first instance' and are part of the declaration of the results (Art 104.1 of Law 19/2002 of 10 October).

- In the general elections, the National Electoral Commission decides 'in the first instance' on the submission of candidate names for election to the legislature. It reviews the legality of the names, signs and symbols (Art 161 of Law 7/2004 of 17 June) as well as the submission of candidate lists by the competent officials of political parties or coalitions. During the general election and the election of the President of the Republic it also decides 'in the first instance' on any complaints or protests (Art 110.1 of Law 7/2004 of 17 June).

\section{THE ‘SECOND INSTANCE'}

Appeals to the instances ad quem (at the end of the process) are not clearly defined by the current legislation. For example, with regard to general elections there are no precise indications of the intention of the legislature in relation to appeals to the provincial elections board against decisions of district and city level elections boards or, in the case of municipal elections, the law permits an appeal to the district or city level election boards against the decisions of voting precinct boards.

In this regard, the interpretation of the electoral law is fundamental and the Constitutional Council is in the process of rationalising and providing coherence to the legal order in this regard.

The electoral legislation establishes a general principle in favour of appeal 'in the second instance' to the National Electoral Commission in the case of complaints and protests by the electoral process support bodies and officials. This general

5 See, for example, the case of José Manteigas Gabriel, the candidate for the position of President of the Municipality of Mocuba, Decision no 3/CC/03 of 19 November. 
principle is not exclusive and other mechanisms for review 'in the second instance' are permitted.

\section{Appeal to the National Electoral Commission on Decisions Taken by Electoral Process Support Bodies and Officials}

Within the scope of its authority the National Electoral Commission has the competence, in terms of Art 7.2(g) of Law 20/2002 of 10 October 'to decide within forty-eight hours the complaints and appeals with regard to decisions taken by the electoral process support bodies and officials'.

The aforesaid bodies $a$ quo (who act at the beginning of the process) are listed in Art 23 of Law 20/2002. They include the provincial election boards and the boards at district and city levels. These bodies have the competence, as defined in Art 96.1 of Law 19/2002 of 10 October and Art 102.1 of Law 7/ 2004 of 17 June, to decide on complaints and protests submitted to them.

These decisions may be appealed 'in the second instance' to the National Electoral Commission. However, the National Electoral Commission cannot, on its own initiative, review decisions of the voting precinct boards or the city election boards, which may decide whether or not the matter is appealed to the National Electoral Commission.

The Constitutional Council had the opportunity to decide whether or not the National Electoral Commission has such an initiative when it validated the electoral results for the interim election of the President of the Municipal Council of the City of Xai-Xai (Decision no 17/CC/04 of 3 June 2004). In that case it decided 'that the procedure adopted by the National Electoral Commission lacks legal foundation'. In addition, this decision damaged the 'principle of the progressive estoppel of acts'.

\section{Specific Appeals 'In the Second Instance'}

In order to identify the specific appellate procedures 'in the second instance' outside of the general rule stipulated by Art 7.2(g) of Law 20/2002 of 10 Octoberit is necessary to analyse the relevant electoral legislation.

In its decision no $17 / \mathrm{CC} / 04$ of 18 June, the Constitutional Council developed a system of appeals in relation to municipal elections which must be taken into consideration to establish a system for appeals in relation to general elections.

\section{Appeals 'in the second instance' in relation to municipal elections}

During the interim election for the President of the Municipal Council of the City of Xai-Xai in 2004, which followed the death of the office-holder on 4 March 2004, the Constitutional Council defined its doctrine with regard to appeals, declaring that the 'voting precinct boards are competent to decide complaints and protests 
that are submitted to them, without prejudice to the appeal of their decision to the district or city election board [author's emphasis]' (Decision no 17/CC/04 of 3 June 2004). Thus, the decisions of the voting precinct boards are subject to appeal to the city and district election boards in terms of the binding decision of the Constitutional Council (Decision no 17/CC/04, of 3 June 2004). 'The district and city election boards' established by the Constitutional Council 'are invested with decisionmaking power, both in the first instance and in the second instance, with regard to the complaints that are submitted to them' (Art 96.1 of Law 19/2002 of 10 October).

The only legal foundation for the decision of the Constitutional Council is the provision set out in Art 75.4 of Law 19/2002 of 10 October. However, the issue remains whether or not there is an appeal to the respective provincial election boards against the decisions of the district and city election boards. Law 19/2002 of 10 October does not make any formal mention of this possibility. During the intermediate phase of determining the vote, the law only establishes that: 'A copy of the minute of the intermediate vote determination is sent immediately by the chair of the district and city election board to the National Electoral Commission through the provincial election board who also keeps a copy of the minute in question' (Art 96.2 of Law 19/ 2002 of 10 October). It does not contain specific formal mention of whether or not the decisions of the district and city election boards may be appealed to the respective provincial election boards in the course of the vote determination process.

\section{Appeals 'in the second instance' in respect of general elections}

Law 7/2004 of 17 June does not, in any of its provisions, provide explicitly for a system of appeals comparable to that established by Law 19/2002 of 10 October; that is, a general appeal mechanism to the district and city election boards against the decisions of the voting precinct boards, as provided for in Art 75.4 of Law 19/ 2002 of 10 October. As Justice João Nguenha wrote: 'Curiously, the law that we have been analysing has no provisions regarding the possibility of appeal of the decisions on complaints and protests issued by the voting precinct boards, which is not the case with Law 19/2002 of 10 October (...), whose Art 75.4 establishes expressly that the decisions of the voting precinct board on such matters are appealable to the respective election board' (Nguenha 2004, p 10).

Only Law 7/2004 of 17 June contains provisions relating to the organisation of the channelling of ballots which have been nullified or regarding which there are complaints or protests to the district or city election boards. According to this law these matters must be taken to the provincial election board, which, in turn, refers them to the National Electoral Commission (Arts 92 and 101 of Law 7/ 2004 of 17 June).

In addition, there is no provision for oversight by the district or city election boards of the decisions made by the voting precinct boards during the partial voting determination. There is only a requirement for inclusion in the minutes of the voting 
procedures and the preliminary determination of the vote of decisions taken by the board during the electoral process (Art 94.2(d) of Law 7/ 2004 of 17 June) and of the number of complaints and protests (Art 94.2(j) of Law 7/2004 of 17 June).

These minutes are sent to the respective district or city election boards who should deliver them to the provincial election board. Thus, during the preliminary determination phase the legislator has not provided for any form of appeal against decisions made by the voting precinct boards to the respective district or city election board.

During the determination of the provincial vote the provincial election boards undertake the determination of the voting results at provincial level but the legislation makes no mention of any mechanism for appeals to the provincial boards against acts carried out by the district or city election boards.

Could it be that the legislator wanted to provide for the appeal against decisions taken by the bodies a quo (at the beginning of the process) to the bodies ad quem at a higher level? Could there be, as Associate Justice João Nguenha argues (2004, p 10), 'an omission that could be overcome by the application of the rule established in Art 75.4 of Law 19/2002 of 10 October'? Or could it be that the legislator has a plan other than a territorial one for the appeal procedure? The principle underlying a response to this issue could be taken from the legislative intent (ratio legis) with regard to appeals.

Within the context of general elections each phase of the electoral process is autonomous in terms of the treatment of appeals. The voting precinct boards must decide on the complaints and protests submitted (Art 78.3 of Law 7/2004 of 17 June). Similarly, provincial election boards must decide on complaints and protests submitted to them and concerning the conduct of the determination of voting at provincial level, the content of which is strictly defined (Art 102 of Law 7/ 2004 of 17 June); but all these decisions may be reviewed by the National Electoral Commission 'provided that the matter appealed has been the subject of a complaint or protest' (Art 173.1 of Law 7/ 2004 of 17 June).

Thus, with regard to the administrative (non-jurisdictional) dispute procedures for the general elections there would appear to exist a centripetal relationship in which the National Electoral Commission directly decides appeals against decisions of the voting precinct boards and the provincial election boards without there having been established an intermediate and higher appeal between the voting precinct board, the district and city election boards and the respective provincial election boards.

\section{Second instance 'Sua Sponte' (on its own motion)}

In the case of complaints about the vote count or the treatment of votes, for instance the nullification of a ballot, which is submitted and not responded to, and which is then referred to the National Electoral Commission, this body decides 'in the second instance' 'regarding the voting ballots in respect of which a complaint or protest 
has been submitted' (Art 102 of Law 19/ 2002 of 10 October; Art 108 of Law 7/ 2004 of 17 June). In such cases the National Electoral Commission reviews and rules on the decision already made by the voting precinct board concerning the vote count or the treatment of a particular vote. Moreover, during the phase of verification of ballots that have been nullified (Art 102 of Law 19/2002 of 10 October; Art 173 of Law $7 / 2004$ of 17 June ) the National Electoral Commission may reconsider these ballots according to uniform criteria and may change the ruling of the voting precinct board. This is an example of the National Electoral Commission exercising 'on its own motion, the reconsideration of the ballots which have been challenged (...) and therefore being unnecessary for the complainant or person making the protest to interpose an appeal' (Nguenha 2004, p 11).

\section{Jurisdiction Over the Electoral Dispute Procedure}

The control of electoral and electorally related political matters comes together in the authority given to the Constitutional Council to review decisions taken during the electoral process (Freire Barros 1998, p 23) and to decide on the regularity and validity of acts committed in the course of the electoral process. In effect, in terms of Art 181.2(c) of the Constitution of the Republic, the Constitutional Council has been given the competence 'to review, in the final instance, electoral claims'.

Expanding on what is established in the Fundamental Law, the legislature has applied these constitutional directions not only to general elections but also to local elections. Thus, in accordance with Art 8 of Law 7/2004 of 17 June, 'the Constitutional Council has the competence to review in the final instance electoral claims and appeals'. Similarly, with regard to disputes about candidacies submitted for local elections 'The decisions of the National Electoral Commission may be appealed to the Constitutional Council who will then decide in the final instance' (Art 20 of Law 19/2002 of 10 October). Again, 'The decisions taken by the National Electoral Commission on claims submitted may be appealed to the Constitutional Council' (Art 138.1 of Law 19/2002 of 10 October).

In addition, the Organic Law of the Constitutional Council details clearly that with regard to matters concerning electoral claims 'The Constitutional Council has the competence to review and decide, in the final instance, in accordance with the terms of the law, the electoral claims and appeals' (Art 75 of Law 9/2003 of 22 October). Therefore, the Mozambican legal order ordains in respect of both national and local elections a system of external electoral control with a jurisdictional character that is independent, exclusive, and impartial.

\section{The Mozambican Electoral Dispute Procedure: An Integrated Process}

The Mozambican electoral dispute procedure is an integrated process in the sense that it provides for dispute resolution procedures from the pre-electoral to the post electoral stages. 
In effect, the jurisdictional activity of the Constitutional Council is carried out both at the level of the pre-electoral dispute procedure (disputes about the submission of candidacies and electoral disputes about electoral administrative acts) and at the level of the post-electoral dispute procedures (disputes about the election of the President of the Republic; disputes about the election of members of the Assembly of the Republic and disputes about the election of members of the local municipal bodies) ${ }^{6}$.

\section{Pre-election Dispute Procedures}

The pre-election procedures correspond 'to the group of disputes that arise from preparation of the election from the moment of the opening of the election campaign, and which may concern controversies arising from the submission of candidacies, the party electoral lists, the organisation of the election campaign etcetera ...' (Freire Barros 1998, p 58).

These disputes concern acts which are based on the doctrine of the 'cascade effect'. This doctrine, which has been developed by the Constitutional Council in several of its decisions, gives force to the principle of the progressive estoppel of acts, pursuant to which 'the different stages of the consummated procedures which have not been contested within the time period allowed for such contestation may not during a subsequent phase of the electoral process be contested' (Decision no 3 / CC/ 2005 of 12 January). In accordance with this principle and paraphrasing Manuel Freire Barros (1998, p 60), 'the procedural phase that has been concluded can nevermore be questioned'.

This type of dispute procedure is divided into two categories: the submission of candidacies and electoral administrative acts.

\section{Disputes About the Submission of Candidacies}

The submission of candidacies follows an established sequence, both in respect of the municipal elections (Arts 13 et seq and Arts 16, 17 and 123 et seq of Law 19/ 2002 of 10 October) and the general elections (Arts 158 et seq of Law 7/2004, of 17 June).

Disputes about the submission of candidacies have, until now, constituted the majority of pre-election disputes ${ }^{9}$. This dispute procedure, which concerns the control of particular acts relating to the submission of candidacies, operates as 'a merely formal examination of the requirements of the qualification of the candidates for the election' (Freire Barros 1998, p 63).

6 With regard to the theoretical distinction between these two types of disputes, see Freire Barros 1998, $\mathrm{p}$ 61 et seq.

7 See, for example: Decision no 2/CC / 03 of 19 November (rejection of the candidacies submitted by the PIMO Party, B.R.47, 19 November 2003, Series I); Decision no 3/CC/03 of 19 November (residence of candidate José Manteigas Gabriel, candidate for President of the Municipality of Mocuba (electoral 


\section{Dispute Procedures Under the Electoral Administrative Acts}

The control of actions of the National Electoral Commission in matters related to the electoral process is entrusted to the Constitutional Council.

As an example ${ }^{8}$, the case that culminated in the decision of the Constitutional Council no 3/CC/ 03 of 19 November as to whether or not José Manteigas Gabriel, candidate for the presidency of the municipality of Mocuba, had the essential requirement for determination of electoral capacity (residence of the candidate Art 6.1 of Law 19/2002 of 10 October) also decided a question related to the challenge to an act of electoral administration.

However, it is an open question whether or not the National Electoral Commission can change the final lists of candidates that have already been published.

The Constitutional Council responded in the negative to this question, and provided the following reason: 'Once the final candidates' lists are issued, in accordance with Art 21 of Law 19/2002 of 10 October, the National Electoral Commission cannot make any change unless there has been a challenge to the list by means of an appeal to the Constitutional Council. This rule is imposed in order to guarantee the necessary transparency and stability to the process' [emphasis added].

The Constitutional Council focused on the system for proving the relevant facts during the process to conclude that the National Electoral Commission carried 'the burden of proof that the candidate did not reside in Mocuba. Since it did not carry this burden and since the Oath of Residence is a document with full presumptive evidentiary force, this presumption can only be overcome if demonstrated to be false.' However, the reasoning with regard to the legal impossibility of the National Electoral Commission altering the final candidate lists is very succinct - the basis is that 'this rule is imposed in order to guarantee the necessary transparency and stability to the process'.

The Constitutional Council could have examined the nature of the act that leads to the issuing of the list of candidates and could have considered all the

capacity)), B.R.47, 19 November 2003, Series I; Decision no 4/CC/03 of 24 November (candidacy of Ernesto Filipe Maússe as candidate for President of the Municipal Council of Xai-Xai), B.R.51, 17 December 2003, Series I; Decision no 5/ CC/ 03 of 25 November (candidacy of Castro Sanfins Namuaca for President of the Municipal Council of Nampula) B.R.51, 17 December 2003, Series I; Decision no 6/CC/ 03 of 27 November (candidacy of Alberto Fafetine Chicuamba for President of the Municipal Council of the City of Manhiça), B.R.51, 17 December 2003, Series I; Decision no 7/CC/ 03 of 25 November (candidacy of José Junior Pene Pagula for President of the Municipal Council of Inhambane), B.R.51, 17 December 2003, Series I; Decision no.9/CC/ 03 of 1 December (candidacy of Djalma Luís Félix Lourenço for President of the Municipal Council of Beira) B.R.51, 17 December 2003, Series I; Decision no 27/CC/2004, 5 November (candidacies of PALMO Party for the Electoral District of Zambézia), B.R.47, 30 November 2004, Series I.

8 See also a decision of the Constitutional Council no 13/CC/04 of 2 January on the appeal against the decision of the National Electoral Commission of 1 November 2003 that approved the 'Instruction no. 40/GDG/STAE/03', entitled 'guide for the correction of material errors occurring during voter registration', in B.R.2, 14 January 2004, Series I; Decision no 20/CC/ 2004 of 22 September (decision of the National Electoral Commission which has as its subject matter an increase in the number of registration posts and voter registration brigade members). 
consequences of changing or not changing the list. It cannot be forgotten that the dispute procedure for electoral administrative acts is essentially a constitutional procedure; this means that notwithstanding the fact that it is constitutionally determined, the nature of the procedure itself does not change. Those acts that are subject to the control of the Constitutional Council are acts of public administration, some of which have the characteristics of administrative acts. In this regard, the National Electoral Commission's act of issuing the lists of candidates is, undoubtedly, an administrative act. ${ }^{9}$

Thus, it is necessary to consider all the legal consequences arising from the administrative nature of the act, namely, in this particular case, the system applying to acts that create rights. More specifically, the principle that is established in Art 217 of the General Code of Conduct for State Employees (EGFE) under the title 'Alteration of acts' could serve as a basis for the decision of the Constitutional Council in this process as a 'General Principle'. According to paragraph 2 of Art 217 , 'Acts that are manifestly or otherwise illegal, even if leading to the creation of a right, may be corrected, suspended or revoked, in accordance with the provisions of the preceding paragraph provided that such acts have not yet produced or taken effect'. This means that acts that are constitutive of rights, and, in the case of José Manteigas Gabriel there is no doubt about this question, it is clear that the acceptance of the candidacy changed the legal status of another and even if the underlying act was illegal, provided that it had produced such an effect it cannot be undone on the initiative of the perpetrator of the act or that person's superior. This means that any act that has been made public as a result of a formal announcement (Art 21 of Law 19/ 2002 of 10 October) limits the power of the National Electoral Commission, requiring it to respect the legal situation that its actions have created to the benefit of another.

\section{Post-Electoral Dispute Procedure}

The post-electoral dispute procedure deals with 'the disputes that arise during the election with regard to the regularity of the electoral act in its narrow sense and the determination and declaration of the election results' (Freire Barros 1998, p 58).

The post-electoral or a posteriori dispute procedure is limited to complaints and protests about irregularities that have occurred in the course of the election and the determination of the results (Freire Barros 1998, p 61).

As an example, in Case no 2/CC/2005 (in B.R.3, 19 January, Series I), the appellant, the Expanded Opposition Front Coalition (FAO), challenged a decision of the National Election Commission in relation to the result of the 2004 general election. The Constitutional Council reviewed the decision, taking into account the grounds put forward by the appellants.

9 Regarding the general theory of what constitutes an administrative act see, for example, Caupers 2001, p 165 et seq. 
Similarly, in Constitutional Council Decision no 4/CC/2005 (in B.R.3, 19 November, Series I) the Renamo-Electoral Union Coalition and its candidate, Afonso Macacho Marceta Dhlakama, appealed the decision of the National Electoral Commission denying its challenge to the release of the election results on the basis that the process for the determination of the results should be annulled and the elections be re-held. In this case, procedural impediments prevented the Constitutional Council from accepting the appeal. ${ }^{10}$

\section{The Organisation of the Electoral Dispute Procedure}

The organisational structure of the electoral dispute procedure has a direct influence on the rules of the procedure.

\section{- The Structure of the Electoral Dispute Procedure -}

\section{A Constitutional Administrative Procedure}

The electoral dispute procedure has the structure of an administrative dispute procedure. Nonetheless, this procedure is a 'constitutional administrative dispute procedure', to paraphrase the terminology of Jorge Miranda (in Freire Barros 1998, p 15), because the Electoral Act and its administration are established directly in the Constitution of the Republic. For this reason it is understood that the Electoral Act is removed from the jurisdiction of the Administrative Tribunal (Art 173 of the Constitution of the Republic). Similarly, it is understood that there are special procedural rules that derive from the principle of democratic participation.

In addition, analysing in more detail the subject matter of appeals within the electoral dispute procedure, the procedure is a legal act of the electoral administration in the widest sense, that is, it comprises 'the group of entities and bodies on which the law has conferred the power of certain legal acts, formalities and transactions that are prerequisites for the formation and expression of the will of the electoral community' (Freire Barros 1998, p 46). There is no difference between the nature of a final executable act by the Public Administration which is subject to the legal oversight of the Administrative Tribunal and the acts of the National Electoral Commission. There is also no difference between electoral administration and other areas of state administration. All are areas of state administration, for example, the National Electoral Commission 'is a State body' (Art 2 of Law 20/ 2002 of 10 October). The differences that do exist are of two types.

The first concerns the category or type of administration in question. The National Electoral Commission is a body that is 'independent of all other public authority' (Art 3 of Law 20/2002 of 10 October ), that is, this body is outside the government hierarchy because its charter is based on a privileged link to the

10 See, as another example, Decision no 15/CC/ 04 of 10 January 2004. 
Constitutional Council ('There is an appeal to the Constitutional Council from the decisions of the National Electoral Commission' (Art 8 of Law 20/2002 of 10 October)) and to the Assembly of the Republic (Parliament) which appoints the members of the Commission (Art 5 Law 20/2002 of 10 October ).

The second difference is that, in terms of the Constitution of the Republic and the relevant legislation (Art 244.2(d) of the Constitution of the Republic; Art 8 of Law 7 / 2004 of 17 June; Art 20 and Art 138.1 of Law 19/2002 of 10 October; Art 75 of Law 9/ 2003 of 22 October; Art 8 of Law 20/ 2002 of 10 October) jurisdiction over disputes arising from acts of the Commission is given to the Constitutional Council and not to the Administrative Tribunal, which has ordinary jurisdiction over the legality of the acts of the Public Administration.

\section{The Theoretical and Practical Consequences of the Qualification that is Adopted}

The consequences of the structure of the electoral dispute procedure are not merely or exclusively academic, there are very significant practical implications, namely those which concern the underlying procedural law and its operational classification.

The current legal regime applicable to the political, electoral dispute procedure, whatever the type of election being held or the type of dispute, adopts an objective concept of the appeal procedure ${ }^{11}$ that arises always as a procedure in response to an act, in this case, the decision of the National Electoral Commission, and not as litigation between parties (Supreme Court decision 13 August 1998). While there are some indications of subjectivity, these are insufficient to alter the fundamental character.

An illustration of this affirmation is reflected in the Supreme Court decision dated 4 January 2000 in Case no 9/RCE/99, Appeal to the Supreme Court by the Renamo Party-Electoral Union Coalition, B.R.1-3rd Supp, 7 January 2000, Series I. The Supreme Court, acting in its interim capacity as the Constitutional Council, attempted to clarify the question at issue. This type of examination would only be permitted under the umbrella of the inquisitorial principle, which, in turn, reflects the objective framework within which the dispute procedure is to guarantee objective legality. 'Sua sponte, on our own initiative', the Supreme Court clarified in the case in question, 'and making use of the authority to supervise the electoral process in order to safeguard the public interest process, the tribunal heard testimony from the directors and technical personnel involved in the electoral administration operations at the central level.'

According to legal doctrine, this approach to the electoral dispute procedure would be classified as a 'full jurisdictional constitutional hearing' (Freire Barros 1998, p 149).

11 See, regarding the principal characteristics of the subjective dispute procedure, Pereira de Silva 1989, p 261 et seq; Vieira De Andrade 2000, p 39 et seq and p 45 et seq. 
The necessary link between electoral law and democratic politics provides the explanation for why, as a general rule, electoral legal norms are considered to be rules of public order. ${ }^{12}$ As Freire Barros (1998, p 121) writes: 'the public character of these rules determines the specific powers of the electoral judge whose duty is to ensure their application, even if not specifically requested by the electoral tribunal petitioner.'

During the voting phase complaints, protests and counter protests can be submitted to the respective voting precinct by any registered voter of that precinct; it is at this level that there is the widest range of active legitimisation activity, which confirms the objective character of the electoral dispute procedure.

All these elements taken together have a common objective - to ensure that the originality or particularity of electoral law is justified 'by its duty to make the democratic principle respected' (Masclet 1989, p 25). In effect, during an election it is important to consider the objective relevance of each voter's will to participate, which, in turn, contributes to the collective will, independently of the subjective motives (Freire Barros 1998, p 81). The direct consequence of taking this aspect into consideration is that only if the acts are invalid can they affect the result. It is not the validity of each individual act of voting that is relevant to the judgement about the validity of the election.

Appeals in electoral matters are not the exercise of a private right, they are acts in the public interest (Masclet 1989, $\mathrm{p}$ 336). The public nature of these norms defines the powers of the electoral judge as a duty to ensure their proper application, even if this duty is not specifically invoked by a party appealing to the Constitutional Council. The electoral judge should not be limited to the frame of the subjective interest of the appellant; rather the judge's review should have the more objective focus of the defence of liberty and the transparency of the expression of the will of the electorate. Consequently, it should be recognised that the judge may take the initiative to examine electoral irregularities (Loic 1962, p 75, cited by Freire Barros 1998, p 129).

This characteristic of electoral law is also reflected in the process of validating the electoral results. This was demonstrated by an extremely interesting debate which took place during the consideration of the election results by the Supreme Court (acting then in its capacity as Constitutional Council) and resulted in a minority dissenting opinion from two judges. This comment on the scope of the powers of the electoral judge is found in the decision of 13 August 1998 that 'Publishes the general determination of the voting results and the respective final tables of results of the Municipal Elections' of 1998.

The preliminary issue that became the focus of the debate was the boundaries of the examination undertaken by the Constitutional Council. In other words,

12 See, for example, the application of the rules regarding ineligibility in the decision of the Constitutional Council no 5/CC/ 2003 of 25 November 2003. 
whether the Supreme Court (in its capacity as the Constitutional Council) could decide facts that had not been specifically raised in the appeal by any of the electoral bodies, political parties, groups of citizens whether or not part of the electorate, candidates and their representatives or individual voters.

The majority of the Court considered that for the judges to decide outside this framework would be to apply these powers beyond their proper limits. The dissenting opinion, however, argued that: 'Contrary to the majority opinion [...] we consider that in the present situation, the procedural rules that confer on the examining judge the broadest power of review with regard to the grounds for its decision should be applied, including the faculty to order an additional examination and determination of the evidence, if considered necessary [principle rule of examination].'

Taking into account the control function of the electoral judge as expressed above, it can be concluded that the position of the majority of the Supreme Court was incompletely developed and did not take into account the particularity of electoral law which is 'to guarantee that the election results conform in fact to the will of the electorate and that this choice be expressed in a free and transparent manner' (Masclet 1989).

Effectively, the position of the majority of the Supreme Court is incomplete because it limited its review to the oversight of the strict regularity or legality of the pre-electoral dispute procedure (disputes regarding the submission of candidate names and the acts of electoral administration). However, this majority opinion did not take into account the fact that the electoral judge also exercises oversight over the liberty and transparency of the will of the electorate. As part of this duty, the electoral judge's objective is to guarantee that the electorate's will is expressed in a way that is sufficiently free and transparent. In this view, the electoral judge has a wide scope of review; as was argued with good reason in the declaration of the vote: 'Our position is based on the fact that the fundamental interest to safeguard in all of this process, and which is linked to the unquestionable right of the citizen and which is of an eminently public nature, is the holding of elections under the fullness of liberty, justice, precision and transparency, so that the State and its bodies, in particular in this case, those of the municipalities, are legitimated.'

The political electoral jurisdiction is notably objective and arises always as a procedure in response to an act - in this case it was the general determination of the vote and the respective final vote statistics for purposes of declaration of the election results - and not as voluntary litigation of the interests of different parties, as the Supreme Court recognised in the aforementioned decision ('Moreover, this arises in the specific context of the elections and not as a procedure between parties ...'). From this perspective, the powers of the electoral judge should be broadly characterised in order to fulfil the judge's duty to guarantee the liberty and genuineness of the determination of the collective will of the electorate.

Thus the electoral judge should not restrict the review to the subjective interests and facts raised by the proponents of the procedure, the goal and perspective of 
the review should be the more objective defence of liberty and transparency of the expression of the will of the electorate. Consequently, the Supreme Court, acting in its capacity as the Constitutional Council, did have the faculty to examine on its own initiative the electoral irregularities and, ex officio, undertake the verification of the facts to determine the truth. ${ }^{13}$

The decision of the Constitutional Council no 16/CC/04 of 14 January 2004 regarding the validation and declaration of the results of the municipal elections of 19 November 2003 carries some indications of this view without committing to a conclusive, defined position regarding the interventionist powers of the electoral judge in such procedures.

Thus, in the aforementioned procedure, after undertaking a perfunctory analysis of the documentation, and having determined that there were errors and omissions, the Constitutional Council instructed the National Electoral Commission to correct the aforementioned errors and omissions. Further, and this is the most interesting part, 'The Constitutional Council held, on the eighth day of this month, in the installations of the National Electoral Commission, a meeting was held with this body and with officials from STAE [Elections Technical Administration Secretariat] to clarify certain doubts and errors, to coordinate certain aspects for the execution and preparation of the documentation required for the validation and declaration of the electoral results.' This decision did not detail the substantive aspects of these operations, namely those related to the process of clarifying some errors or the particular nature of these errors.

However, could it be that the Constitutional Council wished to confirm implicitly the 'principle of examination or evidentiary inquiry sua sponte' (see Declaration of the Vote, in Supreme Court Decision of 13 August 1998)?

\section{Some Rules of the Electoral Dispute Procedure}

The procedure governing electoral disputes inherited from the administrative dispute procedure simple rules, without the formality that burdens judicial procedure. These characteristics are particularly relevant to the appeal procedure, which is part of the electoral dispute procedure and is emblematic of that procedure.

The object of this examination is to take into account those decisions of the Constitutional Council which are particularly relevant to the strictly procedural point of view or to the rules governing this process. A particular focus will be the decisions of the Constitutional Council that analyse in detail the terms imposed by the law on the exercise of electoral jurisdiction, that is, the procedural prerequisites. However, not all the procedural requirements are given the same attention. The assumptions with regard to jurisdiction and competence of the Constitutional Council have not been questioned and thus will not be analysed in this paper.

13 Which the Supreme Court, acting in its capacity as Constitutional Council, effectively did in Case no $9 /$ RCE/99 (decision of 4 January 2000). 
The Constitutional Council has paid particular attention to those procedural requirements which have an impact on the subject matter of an appeal and the socalled 'non-specific' or 'atypical' procedures ${ }^{14}$. These procedural requirements are given special attention because they constitute authentic formal obstacles to any review and decision on the merits of appeals relating to the conduct of the electoral administration.

\section{Requirements With Regard to Subject Matter}

What acts can be the subject of an appeal to the Constitutional Council? Narrowly defined, the only matters that can be appealed in an electoral dispute procedure 'are those that have as their subject the decisions of the National Electoral Commission and whose review and decision is given to the Constitutional Council ...' (Nguenha 2004, p 13). ${ }^{15}$

Thus it is this 'independent' (Arts 2 and 3 of Law 20/2002) body of the state that finalises or renders definitive the process of claims or protests that have been submitted. 'This appeal has as its subject matter the Decision of the National Electoral Commission that decided the claim of the present appellant ...' (Decision no $2 /$ CC / 2005 of 12 January) and 'The permissible subject matter and objective of this appeal is precisely to contest and to have annulled the decision taken by the National Electoral Commission' (Decision no 3/CC/2005 of 12 January. See also, Decision no 19/CC / 04 of 11 August 2004; Decision no 20 / CC / 2004 of 22 September; Decision no 6/CC/03 of 27 November.)

It should be added that in the electoral dispute procedure this decision must have external impact, that is, the impact of the issue decided should be felt in the legal relationships between the National Electoral Commission and the parties who

14 As a general rule, the court-related procedural prerequisites are to be distinguished between those related to the appellants, the subject matter and those designated 'unnamed' and 'undefined'. (See, regarding the general theory, Ferreira Pinto \& Dias Pereira 1992, p 43 et seq and concerning the electoral dispute procedure, Freire Barros 1998, p 86 et seq).

15 Nonetheless, the comparative study of the words used in the electoral laws and in the Constitution of the Republic could raise some doubts. Thus, the oversight exercised by the Constitutional Council is, in terms of the law, on the basis of a 'decision' of the National Electoral Commission (see, for example, Art 138.1 of Law 19/2002 of 10 October), while Art 181 of the Constitution of the Republic uses the word 'complaint'. A 'decision' is not the same as a 'complaint' in the narrow sense of the word. Art 138.1 of Law 19/2002 is perfectly clear in this regard when it provides that: 'From the decisions taken by the National Electoral Commission on complaints submitted are appealable to the Constitutional Council [emphasis added]'. Nonetheless, it can be concluded that at the end of the process it is the Constitutional Council that is going to decide on the substance of the 'complaint' submitted and the grounds there for, but only within the framework of an objective analysis, in the final instance, from a 'decision' of the National Electoral Commission and will not directly decide on the 'complaint'. It is only indirectly that the Constitutional Council judges, in such a case, the relevance of the 'complaint' submitted to the National Electoral Commission. In any event, as was acknowledged more broadly by Justice João Nguenha (2004, p 13): 'With regard to the subject matter of the electoral dispute procedure, our legislature apparently used the terminology "dispute procedure appeal" and "complaint" indiscriminately and without the requisite technical and juridical precision.' 
are legitimately and currently part of the electoral dispute procedure appeal. Otherwise the decision of the National Electoral Commission would not be appealable. This can be deduced from Decision no 13/CC/ 04 of 2 January. In this decision the Constitutional Council established that it is because we were not presented with questions regarding the internal organization of the National Electoral Commission that it is fundamental that this type of decision be promptly communicated to all of the interested parties so that these can in an appropriate and timely manner exercise the rights of claim or appeal that the Law permits. This exercise of rights also depends on the due exercise of the competence of this Constitutional Council [emphasis added].' (See also Decision no 19/CC/04 of 11 August.)

The procedural measure is distinguished by the principle of progressive estoppel, in accordance with the ruling that 'the different stages of the process which have been completed and not timely contested cannot later, at a different phase of the electoral process, be contested' (Decision no 3/Cc/2005 Of 12 January). This principle results from the nature of the electoral process, which is delimited by a 'precise scheduling', intended to guarantee that electoral acts are efficaciously carried out.

In other words, the electoral dispute procedure appeal is only permitted if the so-called irregularities have been the subject of a complaint or protest submitted during and as part of the act which the complaint or protest concerns (Art 173.1 of Law 7/ 2004 of 17 June; Art 137.1 of Law 19/2002 of 10 October).

The object of this rule is to facilitate the conclusion of the administrative procedure, which should culminate with the decision of the National Electoral Commission on the complaints and protests. In other words, what is appealable is the final resolution of the National Electoral Commission as a final or definitive administrative act or 'final decision' in the words of the Constitutional Council in its Decision no 28 / CC / 2004 of 5 November, B.R.47-Supp 30 November 2004, Series I) which, at the same time, defined the legally permitted appeals of the particular situations which that case presented.

The Constitutional Council has, on several occasions, insisted on this rule. For example, in case no $2 / \mathrm{CC} / 2005$ of 12 January, it stated that:

Art 173 of Law 7/2004, of 17 June, the Electoral Law, establishes that the principle of prior contestation requires that the irregularities that occur during the course of the voting, during the preliminary determination of the voting may be reviewed through the instrument of a contentious appeal, provided that the subject matter of the appeal was first challenged or protested as part of the act with regard to which the appeal relates (...) If the appellants do not demonstrate in their papers that they had timely submitted to the National Electoral Commission a complaint or protest concerning the irregularities for the purpose of providing the National Electoral Commission with 
notice and an opportunity to resolve the irregularity (...) the appellants cannot later challenge the decision of the National Electoral Commission when they had not timely protested nor complained regarding the irregularities (...) In conclusion, there is no reason to annul that Decision, since the irregularities invoked by the appellants were not the subject of any complaint or protest at the time when the irregularities occurred (...), There is therefore no decision from which the parties can appeal. The purpose of this rule is to guarantee the public interest of all the citizen electorate and not only the interests of the candidates or the political parties who are competing in the elections.'

\section{Decisions nos 3/CC/2005 of 12 January and 4/CC/2005 of 15 January}

It is, on the one hand, National Electoral Commission decisions on the complaints and protests that may be appealed (see, for example, Decision no 13/CC/04 of 2 January) and, on the other, decisions made by the competent electoral process support bodies and officials (Art 7.2(g) of Law 20/2002 of 10 October).

In contrast, if the appeal was submitted without complying with these requirements, it will be denied at the outset on the basis of the lack of a procedural prerequisite or that the act that is the subject matter of the appeal is not appealable; as the Constitutional Council decided very clearly in Case no 29/CC/2004:

The appellant should have previously submitted a protest to the National Electoral Commission regarding the acts it is now alleging, in accordance with the aforementioned legal provision.

This legal prerequisite not having been complied with, the

Constitutional Council cannot now accept this appeal for review

Decision no 31/CC/2004 of 30 December, B.R.1, 5 January 2005, Series I; Decision no 1/CC/2005 of 12 January, B.R.3, 19 January 2005, Series I; Decision no 4/CC/2005 of 15 January.

\section{The Unspecified Prerequisites}

In common parlance, the term 'unspecified prerequisites' is used to refer to procedural requirements that do not warrant a specific designation or separate treatment (Freire Barros 1998, p 111). Examples of these are certain time limitations, location, and the format to be used in submitting the appeal petition.

\section{Time limits}

In the electoral dispute procedure appeal the period within which the appeal must be brought is particularly short because: 
In case of a dispute, what is important is that the actual result of the election is determined without delay so that no doubts remain regarding the election of those who were legitimately elected, or that those who were elected on the basis of irregularities are not permitted to remain for very long before their mandate is revoked. The respect for the right of suffrage, which is alongside the respect for democracy, requires the rapid correction of anomalous situations.

Masclet 1989, p 343.

Thus, Art 138.2 of Law 19/2002 of 10 October stipulates that 'the appeal is filed within a period of three days from the date of the notice of the Decision by the National Electoral Commission regarding the complaint submitted'. Similarly, Art 175.2 of Law $7 / 2004$ of 17 June establishes that: 'The appeal is filed within a period of three days from the date of the notice of the Decision by the National Electoral Commission regarding the complaint or protest submitted.'

As an example, in the pre-electoral dispute procedure, which, as a general rule, is the basis of the largest number of disputes, complaints and protests, should be decided within a very short time in order not to delay the electoral process. According to Manuel Freire Barros (1998, p 60):

what is certain is that it provides the incontrovertible advantage of provoking an authentic cleansing of the electoral process, so that the voting phase takes place in a climate of certainty, and tranquillity, where there will necessarily result a smaller number of disputes and thereby, an 'amicable' relationship between the electoral judge and the electorate, and thus avoiding or reducing the necessity for the use of appeals as the solution to annul the election or alter the voting results...

Numerous cases have been decided by the Constitutional Council on the basis of time-related issues. ${ }^{16}$ To give a few examples, in the case of the National Party of Mozambique v National Electoral Commission, decided by the Supreme Court, acting in its capacity as the Constitutional Council, on 30 September 2003 (Proc1/RCE/ $2003)^{17}$, the party challenged the decision of the National Electoral Commission, which refused to accept its candidates on the basis that the relevant documentation 'was submitted outside of the time period previously fixed'. The appellant had appeared at the Electoral Technical Administration Secretariat one hour after the period had expired for compliance with the documentation submission

16 See, the decisions of the Constitutional Council regarding time limits: Decision no 2/CC/03 of 19 November; Decision no 4/CC/ 03 of 24 November; Decision no 5/CC/ 03 of, 25 November; Decision no 6/CC/03 of 27 November; Decision no 20/CC/2004 of 22 September; Decision no 7/CC/03 of 25 November; Decision no 7/CC/ 03 of 25 November; Decision no 4/CC/ 2005 of 15 January.

17 In B.R.46, 12 November 2003, Series I. 
requirements. The Supreme Court verified the 'evident' non-compliance with the Law by the particular party and denied the appeal. In this case, the Supreme Court insisted that the dynamic of the electoral process requires 'speed in the execution of the acts which are part of that process that doubly requires compliance with legally fixed time limitations'.

In the case of the appeal submitted by the Renamo-Electoral Union Coalition against the National Electoral Commission Decision no 47 / 2003 of 22 October, one of the causes of action concerned the admission of a member of the coalition as a candidate for the Presidency of the Municipal Council of Xai-Xai (Constitutional Council Decision no 4/CC/2003 of 24 November). The fact that the appeal was submitted after the expiry of the time limit fixed by law (three days as set out in Art 138 of Law 19/2002 of 10 October) was a formal bar to a decision on the merits by the Constitutional Council and 'as a consequence of the decision not to permit the appeal, on the basis of late submission, the Constitutional Council did not recognise the merits of the appeal' (Decision no 2/ CC / 03 of 19 November; See also Decision no 4 / CC/ 2005 of 15 January).

However, the Constitutional Council did create an exception with regard to the issue of ineligibility. In the case of Renamo-Electoral Union Coalition $v$ National Electoral Commission (Decision No 5/CC/2003 of 25 November 2003), the Constitutional Council decided that 'Notwithstanding the untimeliness of the appeal, the Council considers that it should nonetheless review the issue on the merits since the issue is governed by the provisions governing incompatibilities as set out in Art 7 of Law 19/2002 of 10 October.' The basis for rejection is 'those which cannot be considered to have been cured by the lapse of time'. It is, in this case, a question of the application of the rule of truth - a rule of public order (Masclet 1989, p 246).

Previously, the Constitutional Council, in Decision no 1/cc/03 of 17 November in the case of Frelimo Party $v$ National Electoral Commission (in B.R.47, 19 November 2003, Series I) regarding the candidacy of Verdiano Francisco Manivete for the position of president of the Municipal Council of Catandica took the opportunity to emphasise that the need for speed derives from the nature of the electoral process, thus maintaining the jurisprudential position of the Supreme Court in this regard (see, Supreme Court, Proc 1/rce/2003).

Nonetheless, in its first decision, the Constitutional Council resolved a legal question with significant practical impact - that of the formal omission of the time limit for the filing of an appeal against decisions of the National Electoral Commission regarding candidacies. Arts 20 and 24 of Law 19/2002 of 10 October do not lay down any time limits in such cases.

It is evident that if one starts from the supposition already confirmed regarding the 'speed of the electoral process' the Constitutional Council, in order to bring consistency to the application of this requirement, which is inherent to the electoral process, could not avoid deciding, clearly and definitively, the question of the time limit for filing an appeal and the concrete terms of such an appeal. By 
analysing the grounds for the decision of the Constitutional Council on this material, it can be deduced that the Constitutional Council used a rationale based on analogy to solve the problem of the time limit and invoked explicitly the provisions regarding voter registration disputes ${ }^{18}$ and electoral disputes which both provide for a period of three days for the filing of an appeal.

Another solution, perhaps more consistent, particularly in situations where two stipulated periods do not coincide, would be to resort to a broader conceptualisation of the electoral dispute procedure which would take into account all the different disputes that can arise from election matters and not only those that arise during the course of voting and the counting of votes. From this viewpoint, Art 138 of Law 19/2002 of 10 October could be a sound legal basis for determining the practice for filing an appeal on matters concerning disputes about the submission of candidate names.

As one can see in the decisions made by the Constitutional Council, the time limit for a contentious appeal is not treated as a procedural but rather as a substantive time limit. The period for appeal in an electoral dispute procedure includes public holidays, Saturdays, Sundays and other holidays. In effect, given its special nature, the electoral dispute procedure appeal does not admit delays of any type. The time limit runs from the date of effective reception of the decision by the appellant (Decision no 13/CC/ 04 of 2 January) and does not include the date of receipt of the notice of the decision (Decision no 4/CC/ 200515 January).

The period for the electoral dispute procedure appeal corresponds to the period within which the right of appeal may be exercised; as the Constitutional Council established (Decision no 4/CC / 2005 of 15 January; Supreme Court Decision of 30 September 2003 (Case 1/RCE / 2003)): 'The time limitation is compulsory. In other words, the passage of this time period extinguishes the right to exercise the act.' In addition to which, given that the time limit for appeal has a substantive character, the running of the time limit may be determined by judicial notice by the Constitutional Council.

\section{The 'venue'}

The place of the submission of the appeal also came under the scrutiny of the Constitutional Council. Notwithstanding the errors committed by appellants with respect to the identification of the venue for the submission of the petition for appeal, the Constitutional Council has demonstrated its willingness to review the substantive claims, giving priority, above all, to respect for the principle of the right to present a defence.

In Case no 18 / CC / 2004 (Decision no 19/CC / 04, of 11 August 2004) an appeal lodged by Renamo-Electoral Union Coalition against the National Electoral

18 For dispute procedures relating to voter registration see Nguenha 2004, p 5 et seq. 
Commission Decision no 24/2004 of 21 July, regarding the registration of voters residing abroad was submitted directly to the Secretariat of the Constitutional Council (see also Constitutional Council Decision no 20 / CC / 2004 of 22 September).

This case provided an opportunity for the Constitutional Council to explain in detail its 'orientation' regarding the venue for the submission of an appeal petition. The 'orientation that has been unanimously determined' by the Constitutional Council is that 'an electoral dispute procedure case must be submitted at the Secretariat of the National Electoral Commission, the entity whose decision is being appealed'. The grounds for this 'orientation' are merely practical, seeking to carry out 'the procedure with the greatest efficiency and speed'.

The importance of preserving the right of appellants to present a defence was emphasised by the Constitutional Council in its decision. (See, in terms of comparative law, Masclet 1989, p 238. ' Because the petition was submitted directly to the Secretariat of this Constitutional Council, it was necessary to notify the National Electoral Commission to comment, given the necessity to observe the principle of the right to present a defence' (emphasis added). Thus, the Constitutional Council instructed the National Electoral Commission to comment within forty-eight hours.

Even so, some incidents may affect the speedy handling of a case. For example, in Case no 11/CC/03 (Decision no13/CC/04 of 2 January), although the National Electoral Commission had referred the appeal to the Constitutional Council, the appeal file was not sent with its decision, which required the Constitutional Council to request the commission's comment on the appeal.

These decisions of the Constitutional Council make it clear that if an appeal is filed in a place other than that specified by the Constitutional Council this fact will not disqualify the appeal, or, consequently, the consideration of the merits of the appeal. This is an example of the use of the principle pro accione with the purpose of enabling decisions on the merit by means of application of the 'orientations' which are most favourable to the exercise of the right of appeal, which is logical, given the distinct characteristics of Electoral Law in its entirety (Masclet 1989, p 25 et seq).

\section{The Content and Form of Presentation of the Petition}

The petition for appeal must be substantiated. The electoral legislation stipulates that a petition for appeal must specify 'the factual and legal bases, and must be accompanied by all elements of proof' (Art 174.1 of Law 7/ 2004 of 17 June). ${ }^{19}$ With regard to a 'Contentious Appeal', the petition shall 'include a photocopy of the minutes of the assembly in which the irregularity has occurred' (Art 173.3 of Law $7 / 2004$ of 17 June).

The Constitutional Council has, on several occasions, reminded appellants of the need to comply scrupulously with the procedural requirements. Thus, in Case

19 See Art 24.1 of Law 19/2002 of 10 October with regard to the appeal against the admission or refusal of admission of candidates for the local municipal elections. 
no $1 / \mathrm{CC} / 2005$ of 12 January, the council, after reviewing the legal bases of the requirements that determine the permissibility of an appeal (Art 173.3 of Law 7/ 2004 of 17 June), confirmed that 'we have a document in which the appellants do not present any factual or legal justification to substantiate the allegations made as the basis of the appeal'. The consequences of not having complied with this requirement were clearly set out. 'This petition is ineptly drawn and when the initial petition is inept, the appeal is void' (Constitutional Council Decision no 4/CC/ 2005 of 15 January).

In addition, the petition must be accompanied by the elements of proof, as stipulated in Art 173.3 of Law 7/ 2004 of 17 June and as stressed by the Constitutional Council in Decision no 3/CC/ 2005 of 12 January: 'The appellants have the burden of proof regarding the acts alleged. ${ }^{20}$

In case no 1 / CC / 2005, the Constitutional Council noted that 'The petition of the appellants is also not accompanied by any element of proof.'

The jurisprudence of the Constitutional Council on this issue (Decision no 1 / CC / 2005 of 12 January; Decision no 3/ CC/ 2005 of 12 January) has been uniformly that failure to submit the elements of proof required by the provisions of the electoral laws will determine the rejection of the appeal.

Another aspect that has been the subject of review by the Constitutional Council is that of the contradiction between the petition and the underlying cause of the petition. In other words, there is a contradiction between the grounds for the appeal derived from the illegality that applies to the act being challenged (cause of action) and the legal instruments required by the Constitutional Council (petition).

This issue was the subject of particular analysis in case no 4/CC / 2005 in which the Constitutional Council determined that 'the appellants allege that they appealed against Decision no 1/2005 of 3 January of the National Electoral Commission because they did not agree with the decision. Arts 1 through 19 of this petition lay out the allegations against the decision which is being appealed, and conclude that "the National Electoral Commission was incorrect when it based it decision on the fact that the protest of the appellants was not timely or appropriate".' 'Thus', the Constitutional Council continues, 'the appellants do not request that the Constitutional Council should annul the Decision, but rather that it should order the correction of all of the irregularities, in order that the general elections of 1-2 December may be confirmed...' The conclusion of the Constitutional Council was: 'This petition lacks foundation both in terms of the subject matter and in terms of the grounds for the appeal'; which determines that it is not appropriate since there is disjuncture between the petition and the underlying cause of action.

20 See also Decision no 19/CC / 2004, 8 September: 'The appellant has the responsibility (...) to prove that the conditions for foreign voter registration were not created as required by Art 9.3 of Law 18/2002, of 10 October'; Decision no 15/CC/ 04 of 10 January 2004; Supreme Court decision of 4 January 2000 (Proc 9 / $\mathrm{RCE} / 99)$ : 'It is not sufficient to allege the existence of fraud or illegality. It is necessary, as the law stipulates, to present the elements of proof that lead unequivocally to the conclusion that it is in fact true that the acts, which have been denounced, occurred as alleged.' 
As a general rule, with regard to the basic principles that should guide the form and content of the presentation of the petition, Manuel Freire Barros (1998, $\mathrm{p}$ 60; see also Masclet 1989, p 232 et seq) instructs that: 'The presentation and argument of the underlying acts should not limit itself merely to the description of the cause of action. Rather the appeal brief should contain a detailed description of the facts and circumstances that readily demonstrates the existence of the basis for the appeal as well as the content, significance and implication of these grounds. The presentation and argument of the applicable law should set out the legal rules and principles which have been violated and the description of the specific acts that are thereby rendered invalid.'

\section{The Role of the Electoral Judge}

The doctrine has emphasised, with good reason, that 'the most relevant characteristic of the electoral dispute procedure resides in the nature of the powers attributed to the judge of electoral disputes' (Masclet 1989). It could be stated that the electoral judge in Mozambique is at the same time a judge of legality and a judge of the freeness and fairness of the elections, but the distinction depends on the time of the electoral process at which the judge acts.

\section{The Electoral Judge as Judge of Electoral Legality}

Given the nature of the pre-electoral dispute procedure (disputes about the qualification of candidates and about administrative acts) it is generally accepted that the judicial review of these procedures adopts a standard of strict legality. This view has been reiterated by the Constitutional Council in various decisions with regard to the verification of whether or not the acts or procedures being challenged conform to the provisions of the election regulatory laws. ${ }^{21}$

Nonetheless, a simple irregularity is not in itself sufficient basis to determine the annulment of the election. The operative basis is the application of the rule of non-substantive (procedural) defects, according to which, 'for the purposes of annulment of the election, what is material are those irregularities which are susceptible to exercising a decisive or determining influence on the results of the vote' (Freire Barros 1998, p 122). This rule was confirmed unequivocally by Art 176.1 of Law 7/ 2004 of 17 June and Art 139.1 of Law 19/2002 of 10 October.

\section{The Electoral Judge as a Judge of the Freeness and Fairness of Elections}

With regard to the review of the freeness and fairness of the elections, the role of the judge in the electoral dispute procedure is less clear and is subject, at least

21 See, for example, Decision no 1/CC/03 of 19 November; Decision no 2/CC/ 03 of 19 November; Supreme Court Decision of 30 September 2003 (Proc 1/RCE/2003). 
theoretically, to an open debate between at least two positions. On the one hand there is the position that the electoral judge should exercise strict control over the regularity of all the acts and procedures that form part of the electoral process and, on the other, there is the position that the electoral judge should limit the review to controlling and securing the liberty, genuineness and fairness of the expression of the will of the electorate (Loic 1962, p 68 et seq, cited by Freire Barros 1998, p 122).

In the case of the second option, the governing rule is not respect for legality in the strict, formal sense, but rather 'respect for the will of the electorate, in such a way as to guarantee that the electorate's will is expressed in a sufficiently free and fair manner' (Freire Barros 1998, p 122; see, also, Miranda 1998, p 891). In this case the electoral judge must be free to adjust the results of the vote and annul the election. In other words, the mission of the electoral judge is not to punish any and all types of illegal electoral acts but to guarantee the precision and fairness of the vote (Masclet 1989, p 245).

Mozambican law contains an identical provision, applicable to all types of elections, permitting the legislator to give priority to guaranteeing the will of the electorate:

The voting in any voting precinct will only be considered to be null when irregularities have been demonstrated that could materially influence the election results.

Art 176.1 of Law 7/2004 of 17 June; Art 139.1 of Law 19/2002 of 10 October

Thus, the annulment of a general or local election should never be seen as a sanction intended to punish the conduct of a particular party or candidate because the Constitutional Council may only sanction irregularities that could materially influence the results of the elections and then only for the purpose of guaranteeing the true expression of the will of the electorate.

It remains to be determined and defined just what are 'irregularities that could materially influence the election results'. From a theoretical point of view this is an indeterminate legal precept (Bergel 2001, p 115 et seq), that is, 'concepts whose concrete impact cannot be defined in advance, but rather are defined on a case by case approach on the basis of circumstances that have a current as well as a subsequent (...) application and from this point of view do not have a fair, single solution' (García de Enterría \& Fernández 2000, pp 142-143).

This gives the Constitutional Council wide latitude in its review, from which it could be concluded that Parliament has opted for an oversight of the freedom and fairness of the election more than for strict control over the legality of the electoral process. From a comparative law standpoint there are very few situations in which an irregularity on its own results automatically in the annulment of an election. Some examples of cases in which there were found to be grounds for annulment are: the irregular composition of the voting board, the violation of the 
secrecy of the vote and incontestable findings of fraud (Masclet 1989, p 250). The general rule is that the judge examines incidences of irregularity in the voting results and questions whether the result would have been different if the irregularities had not existed (Masclet 1989, p 250).

In other words, the irregularities must have been of such a nature as to affect materially the election results. Irregularities would be considered to meet this test if they were committed with the objective or had the effect of falsifying the election results, especially if they make an impact on the number of votes for each of the candidates or relate to the manipulation of the results.

Thus the electoral judge must take into account factors apart from the act of fraud itself, such as the difference between the number of votes received by the candidates, in order to evaluate the impact of the irregularity on the election results. The smaller the difference, the greater the latitude to determine whether the irregularity may have affected the result. If the difference in the number of votes is sizeable, the fraud or irregularity generally has no impact (Supreme Court Decision 4 January 2000 (Proc 9/RCE/99)). It should be acknowledged, however, that it is not always easy to make such an assessment and a simple violation of the law does not necessarily result in the annulment of an election, as was established by the Constitutional Council in case no 14/CC/ 03 (Decision no16/CC/04 of 14 January 2004), 'These illegalities, although warranting examination, did not affect irreparably the subsequent acts of the electoral process, nor influence the general election results for each municipal office' (see also Supreme Court Decision of 13 August 1998).

With regard to the powers of the Constitutional Council it is necessary to identify the solutions that are technically possible before looking at the positive law.

From a comparative law perspective, three solutions are technically possible: the electoral judge may confirm or annul the election or reform or correct the electoral results with all the consequences that this would elicit with regard to the declaration of the elected candidates (Masclet 1989, p 245).

With regard to the post-electoral dispute procedure, the current electoral legislation establishes a single form of sanction in the event of the determination of invalidity: the annulment of the election (Art 176 of Law 7/2004 of 17 June and Art 139 of Law 19/2002 of 10 October ) thus limiting the powers of the Constitutional Council to either confirm or annul the election?

This dilemma was raised before the Portuguese Constitutional Court, which opted for a decision in favour of correcting the results if that offered a possibility of 'saving' the election (Freire Barros 1998, pp 126-127). ${ }^{22}$ However, even if one agrees with the final decision of the electoral judge, the decision raises the problem of the legal basis of the power to correct the electoral results.

22 It should be noted that Portuguese electoral legislation is identical to that of Mozambique: 'The voting in any voting precinct and the voting in any district shall only be annulled when there are found to exist illegalities that could influence the general results of the district elections', cf, Freire Barros 1998, p 124. 
In this regard, doctrine insists on the principle of universal equal suffrage, which is demonstrated in the electoral process by the requirement that all phases of the electoral process occur simultaneously throughout the electoral territory, particularly the phase of voting. Freire Barros (1998, p 129) argues that:

It should be noted that the simultaneity of the voting process ... is an authentic corollary of another important principle of electoral law, which is that of equal self-determination for all citizens. Since the annulment of an election implies, compulsorily, its subsequent repetition, it is important to see that this fact will affect the principle of simultaneity and will always require an alteration of the terms of equality that should govern the electorate's exercise of its right of suffrage as well as the impact on the candidates affected by the repetition. On this basis it can be concluded that the electoral laws prescribing the annulment of elections in the event of an illegality that would be determinant of the election should be restrictively interpreted. This constitutes, in conclusion, the legal basis which not only argues in favour but requires the electoral judge to opt for a decision in favour of the reform or correction of the voting results (in case of error or illegality) instead of a decision in favour of the annulment of the election.

Until now the Constitutional Council has not made a decision requiring the correction or reform of voting results. Thus it is merely speculative to discuss the legal position of the Constitutional Council should it have to decide this question and whether or not it would decide in favour of the correction of the results.

Another issue, linked to this but with its own significance, is the extent of the power of the electoral judge to reform the election results.

In other words, should the electoral judge only undertake the correction of the election results in cases of voting illegality and material errors in the counting of the votes and in the determination of the results, as in the Portuguese legal system (Freire Barros 1998, p 13), or should the judge's power be viewed as broader, allowing him or her to declare the election of one candidate over another a result of the judgement of concrete circumstances of a particular election, as in the French legal order (Masclet 1989, p 225 et seq)?

These are currently merely highly speculative hypotheses but ones which, sooner or later, will have to be clarified by the Constitutional Council.

\section{CONCLUSION}

The youthfulness of the Constitutional Council contrasts with the maturity of its decisions in electoral matters. Although it only came into being in 2003 the court has already demonstrated a mastery of electoral legal issues. 
It should be praised for this performance, especially in an area of law that is known for its extreme technicality and complexity and in relation to which there are relatively few studies and works of quality.

However, this does not mean that all the legal and electoral problems have been resolved. Delicate questions, such as the scope of the powers of the Constitutional Council, the confirmation or not of the 'principle of sua sponte examination or evidentiary inquiry' and the position of the council in relation to the correction of election results are still unresolved.

It is lawyers who, even more than the electorate, eagerly await the next elections!

\section{REFERENCES}

Bergel, J L. 2001. Méthodologie juridique. Paris: PUF.

Caupers, J. 2001. Introdução ao Direito Administrativo. Âncora Publisher, 6 a ed.

Ferreira Pinto, F B and Dias Pereira. 1992. In G F Fonseca. Direito processual administrativo contencioso, $2^{\mathrm{a}}$ ed. Elcla Editora.

Freire Barros, M. 1998. Conceito e natureza jurídica do recurso contencioso eleitoral. Livraria Almedina-Coimbra.

García de Enterría, E and T R Fernández. 2000. Curso de Derecho Administrativo. Madrid: Ed Civitas, $10^{\mathrm{a}}$ ed.

Loic, Ph. 1962. 'Les attributions et le rôle du Conseil Constitutionnel en matières d'élections et de référendums'. Revue du Droit Public et de la Science Politique en France et à l'Etranger 1 cited by M Freire Barros 1998. Conceito e natureza jurídica do recurso contencioso eleitoral. Livraria Almedina-Coimbra.

Masclet, J C. 1989. Droit électoral. Paris: PUF.

Miranda, J. Preface to M Freire Barros. 1998. Conceito e natureza jurídica do recurso contencioso eleitoral. Lisbon: Livraria Almedina-Coimbra.

Nguenha, J. 'O contencioso eleitoral'. 2004. Presentation made during the Seminar on Electoral Law organised by Centre for Studies on Public Administration and Local Development (NEAD) of the Faculty of Law of the University of Eduardo Mondlane, 22-24 September. Pemba: photocopy.

Pereira de Silva, V. 1989, Para um contencioso administrativo dos particulares (esboço de uma teoria subjectivista do recurso directo de anulação). Lisbon: Livraria AlmedinaCoimbra.

Vieira De Andrade, J. 2000. A Justiça Administrativa. Lisbon: Livraria AlmedinaCoimbra, $3^{\text {a }} \mathrm{Ed}$. 